\title{
The Direct and Indirect Effects of Implicit Beliefs of Intelligence on Academic Achievement in English among High School Students: Goal Orientation as a Mediator
}

\author{
Mohamed Omer Ali Elhassan ${ }^{1}$ \\ Ida Hartina Ahmed Tharbe ${ }^{1}$ \\ Ahmad Shamsuri Muhamad ${ }^{1}$
}

${ }^{1}$ Department of Educational Psychology and Counselling, Faculty of Education, University of Malaya.

Malaysia

Correspondence: Mohamed Omer Ali Elhassan. Department of Educational Psychology and Counselling, Faculty of Education, University of Malaya.Malaysia.Email: dr.m.elhassan@gmail.com 


\section{Abstract}

Introduction. High academic achievement in English is a valued key for high school students in Sudan to guide them toward a better life, career, and social opportunities. At the same time, many of the Sudanese students have linguistic, cultural, and rhetorical problems in the English language, and many of them face challenges in expressing themselves in English. Thus, the core purpose of this study is to explore what may help them in this matter; this includes examining the direct effects of the entity and incremental beliefs of intelligence on academic achievement in English and testing the indirect effects through goal orientation.

Method. A quantitative research method was used by applying scales of implicit beliefs of intelligence (Dweck, 2000) and goal orientation (Elliot \& Church, 1997). The data were collected using a cluster sampling technique from 392 respondents, mainly high school students in Sudan. A structural equation model (SEM-AMOS) of relations among constructs was employed to examine the relationships among the construct variables.

Results. The findings of the structural equation modelling indicated that there was no direct effect of entity belief of intelligence and that there was a direct effect of incremental belief of intelligence on academic achievement in English. Regarding the mediation role of the goal orientation in the relationship between entity belief of intelligence and academic achievement in English, there was no mediation role play. Nevertheless, the goal orientation partially mediated the relationship between the incremental belief of intelligence and academic achievement in English among Sudanese high school students.

Discussion and Conclusion. Academic achievement in English is influenced by students' motivations, beliefs of intelligence, and goal orientations. Accordingly, the English language of Sudanese high school students requires more attention and consideration for the incremental belief of intelligence, goal orientation, and other significant variables in order to support those students in Sudanese high schools to overcome their weaknesses in English and improve themselves so that they can achieve high scores academically in English.

Keywords: Implicit Beliefs of Intelligence; Entity belief; Incremental belief; Goal Orientation; Academic Achievement in English 


\section{Resumen}

Introducción. El éxito académico en la asignatura de lengua inglesa es un elemento clave para los alumnos de educación secundaria en Sudán, porque los puede ayudar a mejorar las oportunidades sociales, profesionales y de calidad de vida en el futuro. Al mismo tiempo, muchos alumnos sudaneses tienen problemas lingüísticos, culturales y retóricos en relación con la lengua inglesa y muchos de ellos tienen dificultades a la hora de expresarse en inglés. El propósito principal de este estudio es explorar cómo se les podría ayudar en este sentido y examinar los efectos directos que ejercen sobre el desempeño académico en inglés las teorías fija y de crecimiento sobre la inteligencia, además de los efectos indirectos de la orientación de meta.

Método. Se usó un método de investigación cuantitativo que consistió en aplicar escalas de teorías implícitas de la inteligencia (Dweck, 2000) y de orientación de meta (Elliot \& Church, 1997). Los datos se recogieron mediante una técnica de muestreo por conglomerados en una muestra de 392 respondedores, fundamentalmente alumnos de educación secundaria en Sudán. Se aplicó un programa de modelado de ecuaciones estructurales (SEM-AMOS) de relaciones entre constructos para examinar las relaciones entre las variables del constructo.

Resultados. Las conclusiones del modelado de ecuaciones estructurales indicaron que la teoría fija de la inteligencia no ejercía un efecto directo sobre el desempeño académico en inglés, mientras que la teoría de crecimiento de la inteligencia sí que ejercía un efecto directo sobre el mismo. En cuanto al papel mediador de la orientación de meta en la relación entre la teoría fija de la inteligencia y el desempeño académico en inglés, no se hallaron efectos directos. Por el contrario, la orientación de meta sí que medió parcialmente en la relación entre la teoría de crecimiento de la inteligencia y el desempeño académico en inglés de los alumnos de educación secundaria sudaneses.

Discusión y conclusión. La motivación, las teorías sobre la inteligencia y la orientación de meta de los alumnos influyen en el desempeño académico en inglés. Por lo tanto, habría que prestar más atención y consideración al desarrollo de la teoría de crecimiento de la inteligencia, de la orientación de meta y de otras variables significativas en los alumnos de educación secundaria sudaneses para ayudarlos a superar la debilidad en inglés y a mejorar su desempeño, de modo que puedan obtener puntuaciones elevadas en la asignatura de inglés.

Palabras clave: teorías implícitas de la inteligencia; teoría fija de la inteligencia; teoría de crecimiento de la inteligencia; orientación de meta; resultados académicos en inglés 


\section{Introduction}

The English language is not the mother tongue of the Sudanese people; despite this, it is considered one of the main subjects at schools in Sudan, where students are encouraged to learn English not only for the marks but also for a promising career and social chances in life. However, the mere attempt to use one of the English language skills by Sudanese high school students in front of others is a matter of fear (Alfadil, 2010). Furthermore, in Sudanese society, English is not generally spoken, and families or parents do not encourage learners at home to practice English except when the examinations are on the doorstep (Labi \& Ahmed, 2005). As Sudanese high school students confront numerous problems in writing, reading, listening, and speaking in English, this is the time for more researches and supplementary methods to support them (Ahmed \& Fadel, 2014; Elmahdi et al., 2015). Sudanese psychological researchers need to find out the most related variables to academic achievement in English.

Meanwhile, researchers have always paid great attention to finding out how variables influence academic achievement and which factors play roles in this aspect. Both individual and environmental variables affect the learners' achievement. There is no doubt that it is difficult to investigate all influencing factors and evaluate all the associated materials and variables related to academic performance in one study. It seems that academic performance is a multi-dimensional factor, and it is affected by vast numbers of variables (Yengimolki et al., 2015).

\section{Implicit Beliefs of Intelligence (IBI)}

The theoretical framework of the current study is driven by Dweck and her colleagues' work (Blackwell et al., 2007; Dweck, 2000; Dweck et al., 1995; Ehrlinger et al., 2016; Hong et al., 1995). Generally, implicit beliefs or theories of intelligence refer to essential beliefs that an individual has about personal qualities (Blackwell et al., 2007). Notably, the IBI are characterised as implicit since it is rarely demonstrated or communicated explicitly. Moreover, the IBI provide an implicit framework that directs the individual's views of a personal characteristic (Champagne, 2015). For the current research, the IBI refer to beliefs related to the malleability of intellectual abilities. Thus, individuals may have a fixed, entity belief of intelligence; or a more malleable, incremental belief of intelligence. Those who have entity beliefs tend to view intellectual ability as something unalterable. Conversely, incremental theorists believe that intellectual ability is something that develops over time (Champagne, 2015). 
Entity theorists see intelligence as constant. In contrast, incremental theorists view intelligence as malleable that may be improved via effort and learning. The IBI are comparatively steady individual differences (Gunderson et al., 2018), which drive people to build distinguishing frameworks for interpreting and making a response to success and failure in academic works (Dweck \& Grant, 2008). Various researches have illustrated that students with entity beliefs are more anticipated to touch the need to validate their intelligence via their performance. Moreover, they are more likely to be attentive and manifest others that are intelligent. However, students with incremental beliefs are more interested in learning and improving their skills and developing their efficiencies (King et al., 2012).

Further, the IBI are attested to significantly influence crucial educational performance such as achievement goals, beliefs in the effort, attributions, self-regulation, and academic success (Blackwell et al., 2007; Dweck \& Grant, 2008; Ehrlinger et al., 2016). Generally, these studies have proven that the maladaptive consequences of having an entity belief and the positive advantages that accrue result from adopting an incremental belief. In other words, the IBI may be described as the individuals' personal realisation about intelligence nature (Dinger \& Dickhäuser, 2013).

\section{IBI and Academic Achievement}

The IBI have been linked with academic performance, and the incremental belief tends to affect positively academic performance (Dinger \& Dickhäuser, 2013). More precisely, those who have incremental beliefs can manage problem-solving skills and increase their efforts to get higher scores in academic tasks. More recently, an incremental belief was found to be influential in academic success, even after controlling the prior stages of achievement (Tarbetsky et al., 2016). Conversely, the individual with the entity belief tends to be at a lower level of academic performance. Researches have also illustrated that students who had the entity beliefs experienced a decline in performance when confronted with failure because they used maladaptive strategies to decrease achievement (Martin et al., 2017). 


\section{Goal Orientations}

Research in goal orientations is considered a very attractive research area in the last few years, and it was extensively addressed in education (Akin \& Cetin, 2007). Further, goal orientations were described as desired personal cognitive representations or undesired outcomes or end states that drive an individual's behaviour. In the academic context, students typically pursue various goals that are concentrated on competence like the goal to demonstrate the abilities to others or to master and understand the learning contents to avert achieving badly compared to others. Thus, goal orientations can be characterised as an individual's cognitive representations of undesired or desired competence-related outcomes or end states in academic achievement contexts (Hulleman et al., 2010).

Harackiewicz and Elliot (1996) tested two types of goal orientation: mastery goal orientation and performance goal orientation. In their work, the mastery goal orientation focuses on developing skills, knowledge, and competency relative to an individual's past performance, and thus, it is self-referential. On the other hand, the performance goal orientation strives to determine competency by outperforming peers on tasks related to the academic field. Further, much literature on achievement goals concentrated on the difference between mastery goals and performance goals. Consequently, learners who adopt mastery goals are inspired to comprehend the material and improve their skills. On the other hand, learners who adopt performance goals compare themselves with others and assess their abilities concerning others to define their self-worth because they are worried about being judged based on their performance (Delavar et al., 2011).

Besides, a distinction was made between two different performance goal orientations: performance-approach goals and performance-avoidance goals (Gheen et al., 2000; Midgley et al., 2001). Moreover, it was proposed that one can be motivated positively to outperform others and demonstrate their superiority and competency, reflecting the general performance goals. Conversely, individuals may have been motivated negatively to avoid failure and avoid looking stupid, dumb, or incompetent, which they label as a performance-avoidance goal to the performance-approach goal.

\section{Goal Orientations and Academic Achievement}

The students' motives to accomplish their tasks are called goal orientation (Dweck, 1986); it includes the predominant ones, the mastery goal orientation and the performance 
goal orientation. On the one hand, students with mastery goal orientation try to obtain knowledge to raise their competence for self-improvement (Bulus, 2011; Buluş, 2016). Thus, these students believe that effort is the issue of failure or success. On the other hand, students with performance goal orientation tend to demonstrate their ability to emphasise high scores to enhance their ego.

In learning, achievement goals reflect the desire to achieve, demonstrate and develop competence in activities and affect how learners respond and commit to other achievement skills (Ames, 1992; Dweck \& Leggett, 1988). Likewise, goal orientations were figured out to be differentially linked with various educational outcomes. For instance, performanceapproach goals were recognised as good predictors of some academic emotions such as selfesteem, whereas performance-avoidance goals are antecedents of hopelessness, shame and anxiety (Pekrun et al., 2006). At the same time, mastery goals, in turn, are steadily associated with many favourable educational findings, for example, involving persistence, deep learning strategy, academic interest or intrinsic motivation (Hulleman et al., 2010). More importantly, performance-approach goals and mastery goal orientation are positively associated with academic success, whereas performance-avoidance goals illustrate negative correlations (Niepel et al., 2014).

Significantly, the mastery goal orientation is considered more adaptive than the performance goal orientation (Kaplan et al., 2002); however, the previous studies showed mixed findings of the prediction of the academic achievement. Very recently, a study showed that mastery goal orientation mainly is a crucial factor for academic performance enhancement (Suprayogi et al., 2019). Besides, Zhou and Wang (2019) proved a positive relationship between goal orientations and academic success, whereas mastery goal orientation, in particular, had a significant positive effect on academic achievement (Delavar et al., 2011). Furthermore, by using SEM, Chen (2015) indicated that mastery goal orientation was associated with academic performance, as well as correlational analysis results revealed significant relationships between goal orientations and academic achievement.

In contrast, it was shown by a mixed model regression that there was no significant relationship between academic success and mastery goal orientation (Neroni et al., 2018). By the same token, Ugur (2016) reported that academic performance is not significantly predicted by mastery goal orientation. Furthermore, mastery goal orientation, which is a characteristic 
of individuals demonstrating an innate desire to develop their competence, does not significantly affect the academic success (Debicki et al., 2016).

A review conducted by Linnenbrink-Garcia et al. (2008) of 90 studies on the relationship between goal orientations and academic achievement illustrated that the relationship between the mastery goal orientation and achievement was positive, about $40 \%$ of the effects reported, and the relationship between the mastery goal orientation and the academic success was negative, which was about $5 \%$ less of the effects reported. The pattern was similar to the relationship between performance goal orientation and academic performance, with $40 \%$ of the effects reported as positive and 5\% reported as negative. However, Pekrun et al. (2009) reported that the mastery goal orientation is often unrelated to performance when all goals are tested together as simultaneous predictors.

\section{Academic Achievement in English (AAE) among High School Students in Sudan}

Academic achievement is defined as learning in a precise setting manifested by teachers' given grades, examination marks and percentiles in academic subjects (Awan et al., 2011). For the current study, AAE refers to the total marks in English subject obtained by high school students out of 100 in the final examinations conducted by the Sudanese Ministry of Education.

The weakness of the AAE among many Sudanese high school students is a common issue in many Arab countries. Students in those countries faced many problems with English language skills, such as listening, speaking, reading and writing (Siong et al., 2014). It was reported that the problem is the difference between the sound system of English and Arabic as one of the main challenges facing the students. English grammar was also another difficulty for the students; instead, they applied the Arabic linguistic approach when writing or speaking English (Mohammed, 2014). Labi and Ahmed (2005) stated that Sudanese high school students made mistakes in writing in English as a second language; furthermore, when the Sudanese learners of English try to use English skills, they seem not to have adequate proficiency in understanding the meaning and semantics (Hago \& Ali, 2015). AbdelRahman and Ahmed (2015) found that Sudanese high school students made many errors in the spoken English language. Besides, students have difficulty with English morphology and/or morphemes (Hammad, 2007). Therefore, the current study has come up with a proposed model of variables guided by past literature to remedy the English achievement challenges that Sudanese 
high school students faced. It is hoped that the findings of this study will provide significant and helpful solutions to the problems.

\section{The Current Study}

The objective of the current study is to examine the direct effects of the entity and incremental beliefs of intelligence on academic achievement in English and testing the indirect effects through goal orientation. In addition, based on the related literature that was reviewed above, the following questions and hypotheses are proposed:

Q1: Does the entity belief of intelligence directly affect academic achievement in English among high school students in Sudan?

$\mathrm{H}_{\mathrm{O} 1}$ : There is no direct and significant effect of entity belief of intelligence on academic achievement in English among Sudanese high school students.

Q2: Does the incremental belief of intelligence directly affect academic achievement in English among high school students in Sudan?

$\mathrm{H}_{\mathrm{O} 2}$ : There is no direct and significant effect of incremental belief of intelligence on academic achievement in English among Sudanese high school students.

Q3: Does goal orientation play a mediation role in the relationship between entity belief of intelligence and academic achievement in English among high school students in Sudan?

$\mathrm{H}_{\mathrm{O} 3}$ : There is no indirect and significant effect of entity belief of intelligence on academic achievement in English via goal orientation among Sudanese high school students.

Q4: Does goal orientation play a mediation role in the relationship between the incremental belief of intelligence and academic achievement in English among high school students in Sudan?

Ho4: There is no indirect and significant effect of incremental belief of intelligence on academic achievement in English via goal orientation among Sudanese high school students. 


\section{Method}

\section{Participants}

The target population consisted of high school students in Sudan. The total number of the target population is (636156) students, and (116659) of them were in the triangular capital of Sudan. While the population was scattered over a wide geographical area, the sample was chosen from the triangular capital of Sudan, which consists of Khartoum, Omdurman and Bahry. It was not possible to select a sample of individuals from a population, and a list of all members of the population of interest was not available, so we used the cluster random sampling technique, and some schools, rather than individuals, were selected randomly. Furthermore, cluster sampling is more effective, with a large number of clusters (Fraenkel et al., 2012). The target sample of the present study was 392 third level students out of the population size, which is considered an acceptable sample size (Piaw, 2013). In addition, we analysed the demographic characteristics of participants through the descriptive statistics of the SPSS. Table 1 below presents the demographic information.

Table 1. Participants' Demographic characteristics

\begin{tabular}{lcc}
\hline \multicolumn{1}{c}{$\begin{array}{c}\text { Baseline } \\
\text { characteristic }\end{array}$} & \multicolumn{2}{c}{ Full sample } \\
\cline { 2 - 3 } & $N$ & $\%$ \\
\hline Gender & 192 & 49 \\
$\quad$ Female & 200 & 51 \\
Male & & \\
Location of schools & 100 & 25.5 \\
$\quad$ Khartoum city & 126 & 32.1 \\
Omdurman city & 166 & 42.4 \\
Bahry city & \\
\hline
\end{tabular}

The table above presents the respondents, 192 were female (49\%), and 200 respondents were male (51\%). About 100 of the participants (25.5\%) lived in Khartoum City, 126 of them (32.1\%) lived in Omdurman City, while the rest of the respondents, 166 (42.4\%), lived in Bahry City. The three cities are called the triangular capital of Sudan.

\section{Instruments}

First and foremost, students' AAE is measured using the Sudanese standardised achievement test of English made by the Ministry of Education in Sudan. It measures abilities that are acquired in educational institutions and are curriculum-based. More precisely, a 
standardised achievement test is an exam that evaluates skills and knowledge that are taught and/or obtained at school (Spinath, 2012).

The researchers compiled three sets of questionnaires to conduct the survey. Guidelines and instructions were provided on the questionnaires, such as demographic information and a brief description of the survey. The second section included an adapted survey of IBI. The third section consisted of an adapted goal orientations survey.

The IBI questionnaire was developed by Dweck (2000) and was assessed using a selfreported scale (Dweck, 2000). The questionnaire contains eight items; each was assessed on a 6-point-Likert-type scale (from $1=$ strongly disagree to $6=$ strongly agree). A composite score was created by taking the average of each item and calculating them to get the excellent scores that represent firmer entity belief. The total scores ranged from 1.0 to 6.0. This measure is often divided into an entity and incremental groups chosen to preserve the total score as a continuous variable. This dichotomisation of a continuous measure is not recommended (Dormann et al., 2013). However, internal consistency was quite right at ( $\alpha=.93$ ).

The goal orientations questionnaire that was created by Elliot and Church (1997), was chosen for this study, and the scale was used to test participants' adoption of the mastery goal orientation, performance-approach goal and performance-avoidance goal in their personality. A pilot study was conducted to develop the scale in which item pools for each goal orientation were generated and examined correlations with other relevant measures and factor analysis. Six items were carefully selected to represent the component universe of each of the threegoal orientations constructs. Participants illustrated the extent to which they agreed with each item to match their beliefs on 1 (not at all true of me) to 7 (very true of me) scales. Furthermore. internal consistency was $(\alpha=.89)$ (Elliot \& Church, 1997).

The measurement validity and reliability were tested. Regarding validity, five professionals in psychology and education performed face validity. In order to raise the correlation between the constructs of the scale called convergent validity (CV), the average variance extracted (AVE) was tested. CV is achieved if the value of AVE gets the minimum level in each construct for the model. AVE should be higher than 0.5 (Hair et al., 2014). Besides, the composite reliability (CR) and Cronbach's Alpha of the constructs were tested in order to test the reliability. The range between .70 to .90 is a considerable value for Cronbach's Alpha, and the 
value of 0.7 and above for the CR showed an acceptable internal consistency (Hair et al., 2014). Table 2 below presents loadings of scales items, Cronbach's Alpha, CR and CV.

Table 2. Results of Reliability and Validity of the Scale

\begin{tabular}{|c|c|c|c|c|}
\hline Questionnaire items & $\begin{array}{c}\text { Cronbach's } \\
\alpha(>0.7)\end{array}$ & $\begin{array}{c}\mathrm{CR} \\
(>0.7)\end{array}$ & $\begin{array}{c}\text { AVE } \\
(>0.5)\end{array}$ & $\begin{array}{l}\text { Factor } \\
\text { loading }\end{array}$ \\
\hline Goal orientation scale & .84 & & & \\
\hline Factor 1: Mastery goal orientation & & .89 & .60 & \\
\hline $\begin{array}{l}\text { 1. I want to learn as much as possible from } \\
\text { English course. }\end{array}$ & & & & .854 \\
\hline $\begin{array}{l}\text { 4. It is important for me to understand the } \\
\text { content of English course as thoroughly as } \\
\text { possible. }\end{array}$ & & & & .621 \\
\hline 7. I hope to have gained broader or deeper & & & & .890 \\
\hline $\begin{array}{l}\text { knowledge of the content when I am done } \\
\text { with English course. }\end{array}$ & & & & \\
\hline $\begin{array}{l}\text { 10. I want to completely master the material } \\
\text { presented in English course. }\end{array}$ & & & & .504 \\
\hline $\begin{array}{l}\text { 13. In a course like this, I prefer class materi- } \\
\text { als that arouse my curiosity, even if they are } \\
\text { difficult to learn. }\end{array}$ & & & & .870 \\
\hline $\begin{array}{l}\text { 16. In the class, I prefer class materials that } \\
\text { really challenge me so I can learn new things. }\end{array}$ & & & & .838 \\
\hline $\begin{array}{l}\text { Factor 2: Performance-approach goal orienta- } \\
\text { tion }\end{array}$ & & .87 & .56 & \\
\hline $\begin{array}{l}\text { 2. It is important to me to do better than the } \\
\text { other students in English course. }\end{array}$ & & & & .884 \\
\hline $\begin{array}{l}\text { 5. My goal in English course is to get a better } \\
\text { grade than most of the other students. }\end{array}$ & & & & .833 \\
\hline $\begin{array}{l}\text { 8. I am working hard to demonstrate my abil- } \\
\text { ity relative to others in English course. }\end{array}$ & & & & .875 \\
\hline $\begin{array}{l}\text { 11. I am motivated by the thought of outper- } \\
\text { forming my peers in English course. }\end{array}$ & & & & .885 \\
\hline $\begin{array}{l}\text { 14. It is important to me to do well compare } \\
\text { to others in English course. }\end{array}$ & & & & .417 \\
\hline
\end{tabular}


Table 2 (Continued). Results of Reliability and Validity of the Scale

\begin{tabular}{|c|c|c|c|c|}
\hline Questionnaire items & $\begin{array}{c}\text { Cronbach's } \\
\alpha(>0.7)\end{array}$ & $\begin{array}{c}\mathrm{CR} \\
(>0.7)\end{array}$ & $\begin{array}{l}\text { AVE } \\
(>0.5)\end{array}$ & $\begin{array}{l}\text { Factor } \\
\text { loading }\end{array}$ \\
\hline $\begin{array}{l}\text { 17. I want to do well in English course to } \\
\text { show my ability to my family, friends, advi- } \\
\text { sors, or others. }\end{array}$ & & & & .419 \\
\hline $\begin{array}{l}\text { Factor 3:Performance-avoidance goal orienta- } \\
\text { tion }\end{array}$ & & .88 & .57 & \\
\hline $\begin{array}{l}\text { 3. I often think about, "What if I do badly in } \\
\text { English class?" }\end{array}$ & & & & .882 \\
\hline $\begin{array}{l}\text { 6. I worry about the possibility of getting a } \\
\text { bad grade in English course. }\end{array}$ & & & & .404 \\
\hline $\begin{array}{l}\text { 9. My fear of performing poorly in English } \\
\text { course is often what motivates me. }\end{array}$ & & & & 696 \\
\hline $\begin{array}{l}\text { 12. I am afraid that if I ask my instructor a } \\
\text { "dumb" question, they might not think I'm } \\
\text { very smart. }\end{array}$ & & & & .666 \\
\hline $\begin{array}{l}\text { 15. I just want to avoid doing poorly English } \\
\text { course. }\end{array}$ & & & & .872 \\
\hline 18. I wish English course was not graded. & & & & .898 \\
\hline Implicit beliefs of intelligence scale & .71 & & & \\
\hline Factor 1: Entity belief of intelligence & & .91 & .72 & \\
\hline $\begin{array}{l}\text { 1. You have a certain amount of intelligence, } \\
\text { and you can't really do much to change it. }\end{array}$ & & & & .802 \\
\hline $\begin{array}{l}\text { 2. Your intelligence is something about you } \\
\text { that can't change very much. }\end{array}$ & & & & .862 \\
\hline $\begin{array}{l}\text { 4. To be honest, you can't really change how } \\
\text { intelligent you are. }\end{array}$ & & & & .857 \\
\hline $\begin{array}{l}\text { 6. You can learn new things, but you can't re- } \\
\text { ally change your basic intelligence. }\end{array}$ & & & & .873 \\
\hline Factor 2: Incremental belief of intelligence & & .93 & .77 & \\
\hline $\begin{array}{l}\text { 3. No matter who you are, you can signifi- } \\
\text { cantly change your intelligence level. }\end{array}$ & & & & .892 \\
\hline $\begin{array}{l}\text { 5. You can always substantially change how } \\
\text { intelligent you are. }\end{array}$ & & & & .882 \\
\hline $\begin{array}{l}\text { 7. No matter how much intelligence you } \\
\text { have, you can always change it quite a bit. }\end{array}$ & & & & .881 \\
\hline $\begin{array}{l}\text { 8. You can change even your basic intelli- } \\
\text { gence level considerably. }\end{array}$ & & & & .869 \\
\hline
\end{tabular}

Table 2 shows the factor loadings confirmed that all constructs have adequate levels of convergent and discriminant validity. Moreover, the reliabilities of all the constructs were above 0.7. All CR values are significantly higher than 0.7 , which represents an acceptable 
level for exploratory research. The AVE values of all constructs are greater than 0.5 ; therefore, CV is achieved. Thus, all the constructs and variables used in this study are based on well-established instruments with high-reliability scores, and the internal consistency of each construct is substantiated to be very good.

\section{Procedure}

In order to conduct this study, an approval letter was issued from the Ministry of Education in Sudan to distribute the scale to Sudanese high school students. Furthermore, the participants were informed of their rights, and an explanation of the purpose of the study has been presented. Besides, all scale's items were translated from English into the Arabic language by an expert in translation and were reviewed by experts in educational psychology. Then, the questionnaire has been re-translated into English to ensure that the translation was accurate and to confirm content-related evidence of validity. Next, the participants filled out the questionnaires that included a demographic survey, IBI scale, and goal orientations scale, while AAE scores were obtained from students' records. Things for sure, the questionnaires were distributed by hand to the identified representatives that have been chosen earlier.

\section{Design}

The current study employed a quantitative research design that reflects postpositivist philosophical assumptions. A correlation design was also used that focused on the survey questionnaire.

\section{Results}

\section{Model Fit and Hypotheses Testing by SEM-AMOS}

This part illustrates the findings of the model fit, regression weight, and hypotheses testing. Further, data was analysed using the SPSS V.22 and AMOS 23. Figure 1 below shows the model fit indices of the SEM using AMOS. 


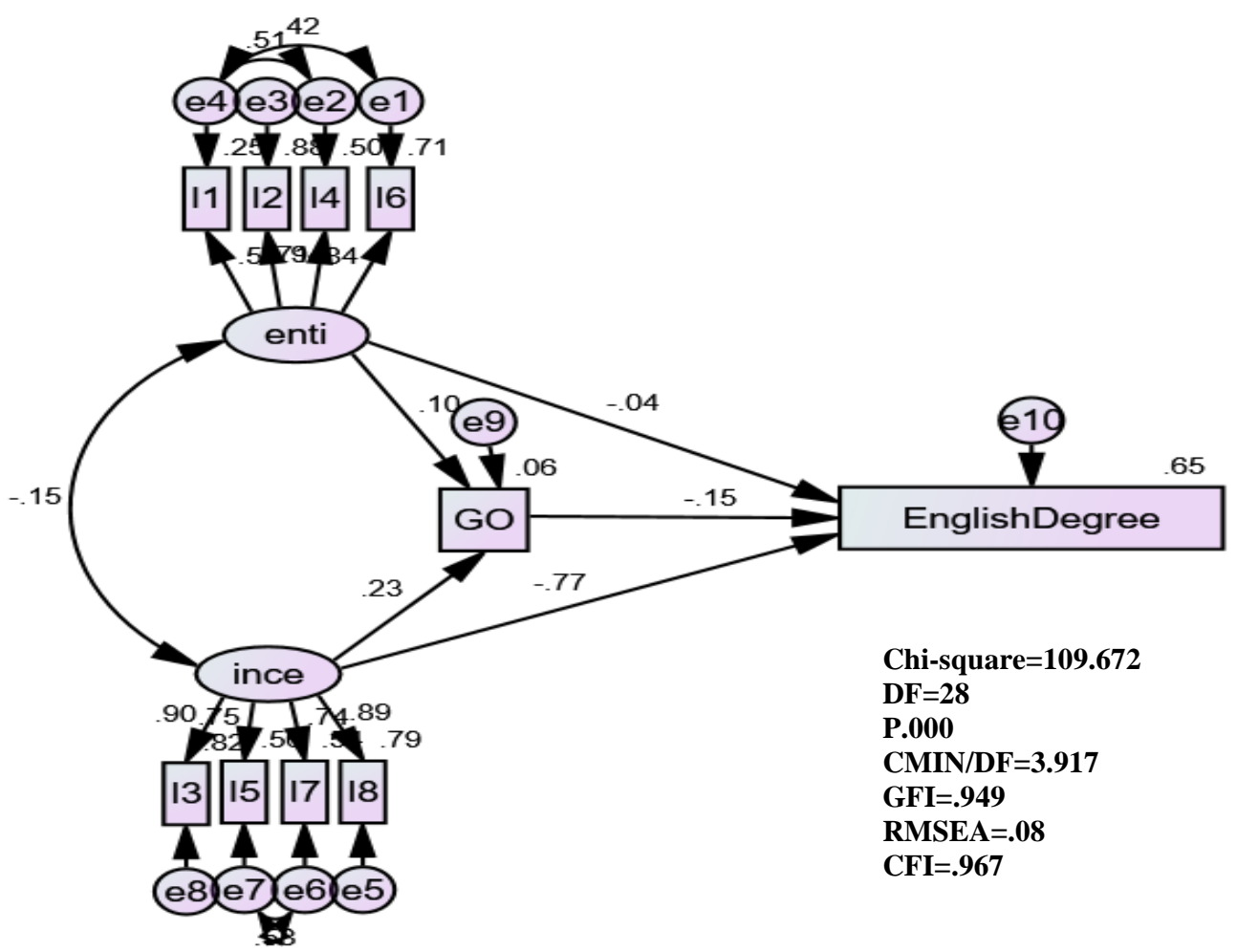

Figure 1. Model Fit

\section{Model Fit}

As shown in Figure 1 above, the results show that the value of $\mathrm{P}=.000(>0.001)$ was significant; however, the findings also portrayed that Chi-square $\left(\mathrm{X}^{2}\right)$ was 109.672 , with a degree of freedom (df) of 28; the Chi-square was above the value with the parsimonious fit. The value of the RMSEA was .08, which is within the acceptable range (Schumacker \& Lomax, 2016). The value of the CFI is .967, which is also considered as an acceptable value of model fit (Awang, 2014). Finally, the relative chi-square (CMIN/DF) is 3.917, between the threshold value of 3.0 and 5.0, which is suggested by Hair et al. (2016). The figure above proves that the model had fulfilled the requirement of the perfect fit. The minimum level was achieved, and all the values indicated good fits according to the criteria of model fit, which is suggested by Schumacker and Lomax (2016). 
Regression Weights

Table 3. The Standardised and Unstandardised Regression Weights

\begin{tabular}{lcc}
\hline \multicolumn{1}{c}{ Effect } & Standardised estimate & Unstandardised estimate \\
\hline $\mathrm{EB} \rightarrow \mathrm{GO}$ & .103 & .037 \\
$\mathrm{IB} \rightarrow \mathrm{GO}$ & .231 & .084 \\
$\mathrm{~EB} \rightarrow \mathrm{AAE}$ & -.042 & -.032 \\
$\mathrm{IB} \rightarrow \mathrm{AAE}$ & -.765 & -.582 \\
$\mathrm{GO} \rightarrow \mathrm{AAE}$ & -.149 & -.311
\end{tabular}

Note. $\overline{\mathrm{EB}} \rightarrow \mathrm{GO}=$ effect of entity belief on goal orientations; $\mathrm{IB} \rightarrow \mathrm{GO}=$ effect of incremental belief on goal orientations; $\mathrm{EB} \rightarrow \mathrm{AAE}=$ effect of entity belief on $\mathrm{AAE} ; \mathrm{IB} \rightarrow \mathrm{AAE}=$ effect of incremental belief on $\mathrm{AAE}$; $\mathrm{GO} \rightarrow \mathrm{AAE}=$ effect of goal orientations on AAE.

The table above indicates that the standardised estimate of the effect of entity belief on goal orientations was .103, and its unstandardised estimate was .037. The standardised estimate for the effect of incremental belief on goal orientations was .231, and .084 was the unstandardised beta. Further, the standardised and unstandardised estimate for the effect of entity belief on AAE was -.042 and -.032 , respectively. Furthermore, the standardised estimate for the effect of incremental belief on AAE was -.765, while the unstandardised beta of it was -.582. Regarding the effect of goal orientations on AAE, the standardised estimate was -.149, while the standardised beta was -.311 .

\section{Analysis of Covariance}

The results of the analysis of covariance were obtained from Figure 1 above and further presented in Table 4 below.

Table 4. Results of Covariance

\begin{tabular}{lcccc}
\hline \multicolumn{1}{c}{ Covariances } & Estimate & S.E & Critical Ratio & P-Value \\
\hline EB $<-->~ I B$ & -.280 & .107 & -2.603 & .009 \\
e6 <--> e7 & .604 & .070 & 8.607 & $* * *$ \\
e2 <--> e4 & .857 & .093 & 9.198 & $* * *$ \\
e1 <--> e4 & .536 & .070 & 7.692 & $* * *$ \\
\hline
\end{tabular}

Note. S.E = Standard Error EB = entity belief; IB = incremental belief; e = error or residual. 
Based on table 4 above, it is evident that the EB <--> IB estimate was -.280 with a standard error of .107 . The critical ratio was -2.603 , while the p-value is at 0.009 . The estimate of e6 <--> e7 was .604 with a standard error of .070; the critical ratio was 8.607, and these items were considered significant at $\mathrm{p}<0.001$. The estimate of e2 <--> e4 was .857 with a standard error of .093; the critical ratio was 9.198, and these items were considered significant at $\mathrm{p}<0.001$. The estimate of e1 <--> e4 was .536 with standard error of .070 ; the critical ratio was 7.692 , and $\mathrm{p}<0.001$. These results imply that all items in the covariance analysis were significant based on the p-value results.

\section{Hypotheses Testing}

The findings of hypotheses testing are presented in Table 5 below, and the analysis was done using AMOS 23. Four null hypotheses of this study were examined based on the results of the path coefficient $(\beta)$, C.R value $>1.96$, p-value $<0.05$. These values were suggested by Hair et al. (2016) to help researchers accept or reject the tested hypothesis. The null hypothesis will not be accepted if the p-value is equal to or less than the significant level of $\leq 0.05$. The alternative hypothesis will be accepted in this case, while the null hypothesis was rejected (Hair et al., 2014). Table 5 presents the findings of the hypotheses testing.

Table 5. The Results of Hypotheses Testing

\begin{tabular}{llcccc}
\hline No & \multicolumn{1}{c}{ Hypotheses } & $\beta$ & $\begin{array}{c}\text { C.R-Value } \\
(>1.96)\end{array}$ & $\begin{array}{c}\text { P-Value } \\
(<0.001)\end{array}$ & Decision \\
& & & -1.213 & .225 & Accepted \\
\hline Ho1 & EB $\rightarrow$ AAE & -.032 & -19.180 & .000 & Rejected \\
Ho2 & IB $\rightarrow$ AAE & -.582 & -1.714 & .070 & Accepted \\
Ho3 & EB $\rightarrow$ GO $\rightarrow$ AAE & -.012 & -2.888 & .004 & Rejected \\
Ho4 & IB $\rightarrow$ GO $\rightarrow$ AAE & -.026 & & & \\
\hline
\end{tabular}

Note. Significant level $P<0.05 . \beta=$ path coefficient; C.R. $=$ Critical Ratio; $\mathrm{EB} \rightarrow \mathrm{AAE}=$ no direct and significant effect of entity belief on academic achievement in English; IB $\rightarrow$ AAE $=$ no direct and significant effect of incremental belief on academic achievement in English; $\mathrm{EB} \rightarrow \mathrm{GO} \rightarrow \mathrm{AAE}=$ no indirect and significant effect of entity belief on academic achievement in English via goal orientation; IB $\rightarrow$ GO $\rightarrow$ AAE $=$ no indirect and significant effect of incremental belief on academic achievement in English via goal orientation.

The above table presented the SEM analysis, and the findings supported the first and the third null hypotheses, while the results did not support the second and the fourth null hy- 
potheses. The following sections include more clarification regarding the hypotheses testing based on the results of the table above.

The Effect of Entity Belief of Intelligence on AAE.

The results accept the first null hypothesis Ho1. It was indicated that the null hypothesis Hol had been accepted and rejected the alternative one. The effect of the entity belief on AAE was $(\beta=-.032, C . R=-1.213, p<.225)$. The value of $\beta$ referred to that there is no direct effect of the entity belief on the AAE. Further, C.R-value was lower than 1.96, and the pvalue was not significant. Based on these values, the null hypothesis was accepted. Therefore, there was no direct effect of the entity belief on the AAE among the Sudanese high school students.

\section{The Effect of Incremental Belief of Intelligence on AAE.}

The results failed to accept the second null hypothesis Ho2. Hence, the null hypothesis has been rejected. The effect of the incremental belief on AAE was $(\beta=-.582, \mathrm{C} . \mathrm{R}=-19.180$, $\mathrm{p}<.000)$. The value of $\beta$ indicated a direct effect of the incremental belief of intelligence on the AAE. Also, the CR value was higher than 1.96, and the p-value was significant. Based on that, the results rejected the null hypothesis and accepted the alternative one. Hence, there was a direct effect of the incremental belief of intelligence on the AAE among Sudanese high school students.

\section{The Mediation Role of Goal Orientations between Entity Belief of Intelligence and AAE.}

The results accept the third null hypothesis Ho3. It was indicated that the null hypothesis Ho3 had been accepted and rejected the alternative one. The results of the mediation role of goal orientations between the entity belief and the AAE were $(\beta=-.012, C$. R=-1.714, $\mathrm{p}<.070)$. The value of $\beta$ referred to that there is no indirect effect of the entity belief on the AAE via goal orientation. Further, C.R-value was lower than 1.96, and the p-value was not significant. Based on these values, the null hypothesis was accepted. Therefore, there was no indirect effect of the entity belief on the AAE via goal orientations among Sudanese high school students. 
The Mediation Role of Goal Orientations between the Incremental Belief of Intelligence and $A A E$.

The results did not accept the fourth null hypothesis Ho4. Hence, the null hypothesis has been rejected. The results of the mediation role of goal orientations between the incremental belief and the AAE were $(\beta=-.026, \mathrm{C} . \mathrm{R}=-2.888, \mathrm{p}<.004)$. The value of $\beta$ indicated an indirect effect of the incremental belief on the AAE via goal orientation. Also, the C.R-value was higher than 1.96, and the p-value was significant. Based on that, the results did not accept the null hypothesis and accepted the alternative one. Hence, there was a partial indirect effect of the incremental belief on AAE via goal orientation among Sudanese high school students.

\section{Discussion and Conclusion}

In Sudanese high schools, intelligence and implicit intelligence receive considerable attention in educational situations. Many students are seeking to know their level of intelligence to increase and improve it. There are differences between students in their intelligence perspectives. Some of them see that intelligence as a trait they were born with, while others see intelligence as an ability that can be developed. Indeed, several studies could document that students holding an entity belief earn lower grades than those holding an incremental belief (Martin et al., 2017), especially when schoolwork becomes challenging. Thus, Sudanese students who regard intelligence as an entity belief sometimes notice despair and lack of academic effort. Those who view intelligence as incremental belief tend to make more effort to achieve highly in academics.

The findings illustrated no direct effect of the entity belief on academic performance among Sudanese high school students. Thus, individuals who hold entity beliefs tend to believe that abilities and skills are relatively steady (Blackwell et al., 2007) and that their AAE is not affected by that stability. In line with this result, many studies have been conducted in the academic field that showed that students who hold entity beliefs have a powerful inclination to impute their failures to a fixed trait (Blackwell et al., 2007; De Castella \& Byrne, 2015; Martin et al., 2017). They are more likely to blame their intelligence for weak performance and impute failures for their inadequate intellectual ability.

The result also indicated that any increase or decrease in the incremental belief of Sudanese students at the high schools directly affects their performance in English. Recently, it 
was suggested that an incremental belief could predict and contribute to academic success (Costa \& Faria, 2018), even after controlling the prior levels of achievement (Martin et al., 2017). In line with this finding, Tarbetsky et al. (2016), by path analysis, presented that incremental beliefs of intelligence positively predict academic performance. Also, another study indicated that IBI might have important implications for students' engagement, motivation, and performance in school (De Castella \& Byrne, 2015). Based on this realisation, it seems crucial for the educators or teachers to assist in helping students change their mindset towards incremental beliefs of intelligence in order to increase their motivation towards learning and setting better goals in English academic performance. This effort can be supplemented with additional classes, tutorials, materials, and practice to increase English language proficiency and academic achievement among Sudanese students.

This study reveals that the goal orientations do not play a mediation role in the relationship between the entity belief and the AAE. Additionally, the findings show that the goal orientations partially mediated the relationship between the incremental belief and the AAE among Sudanese high school students. As stated earlier, the incremental belief (the belief that intelligence is modifiable) directly affected the AAE, so the mediation role of the goal orientations is considered a partial mediation. In line with this result, it was reported that the relationships between academic success and IBI were fully mediated by both performance goal orientations (Diaconu-Gherasim et al., 2018). Furthermore, Chen and Wong (2014) revealed that the incremental beliefs of intelligence contribute to students' academic performance by facilitating their endorsement of performance-approach goals and mastery goals. Another result illustrated that goal orientation has a mediating role between IBI and academic performance (Delavar et al., 2011).

\section{Conclusion}

This study's findings may be considered a light upon the nature of the AAE for Sudanese high school students, their parents, and English teachers, educational policymakers in the Ministry of Education, researchers, educational psychologists, and counsellors. The importance of the IBI and the goal orientations is that they help students of Sudanese high schools to achieve the desired outcomes in the English language. The AAE and other types of academic achievement are influenced by students' motivations, beliefs, and orientations. The students need to pay more attention and consideration to the incremental beliefs and goal orientations; this would help the students in Sudan achieve high English scores. 
Overall, the SEM results indicate that there was no direct effect of the entity belief, and there was a direct effect of the incremental belief on the AAE. Regarding the mediation role of the goal orientations, the results indicated that the goal orientations have no mediation role in the relationship between the entity belief and the AAE. In contrast, goal orientations partially mediated the relationship between the incremental belief and the AAE among Sudanese high school students.

\section{Limitations and future research}

Some limitations are noted in this study, and this leads to suggestions for future research. One of those limits is the study sample. The sample was focused on high school students in Sudan, knowing that scientific studies indicate that Sudanese university students also face many challenges regarding the English language (Alfaki, 2015; Ali, 2013; Benyo, 2014). Therefore, future studies may be extended to Sudanese university students and test the extent of the direct and indirect effects of implicit beliefs of intelligence on academic achievement in English. Besides, the data of this study was only collected from the capital of Sudan, which consists of three cities (Khartoum - Omdurman - Bahry). Therefore, future studies can include random samples from other Sudanese cities, allowing results generalisation. Last but not least, regarding the mediation role, this study examined goal orientations as one compounded factor, so it might be helpful for future studies to address all three dimensions of the goal orientations separately and to measure the extent to which each of them plays a mediating role in the relationship between implicit beliefs of intelligence and academic achievement in English.

\section{Acknowledgement}

This research received no grant from any public or private sectors or agencies.

\section{References}

AbdelRahman, A. K. M., \& Ahmed, Y. A. (2015). Investigating Main Causes of Errors in Sudanese Secondary School Students Spoken English: A Case Study of Some Secondary School Students in Omdurman Locality, Khartoum State. Journal of Science and Technology, 16(1).

Ahmed, I., \& Fadel, A. (2014). A comparison between topic signals and strategies in expository essays in English and Arabic University Malaya].

Akin, A., \& Cetin, B. (2007). Achievement goal orientations scale: The study of validity and reliability. 
Alfadil, A. S. (2010). Strategies for Developing English Oral Communication in Sudanese Secondary Schools Sudan University of Science and Technology].

Alfaki, I. M. (2015). University Students' English Writing Problems: Diagnosis and Remedy.

Ali, E. M. T. (2013). Pronunciation problems: Acoustic analysis of the English vowels produced by Sudanese learners of English. International Journal of English and Literature, 4(10), 495-507.

Ames, C. (1992). Achievement goals and the classroom motivational climate. Student perceptions in the classroom, 1, 327-348.

Awan, R.-U.-N., Noureen, G., \& Naz, A. (2011). A Study of Relationship between Achievement Motivation, Self Concept and Achievement in English and Mathematics at Secondary Level. International Education Studies, 4(3), 72-79.

Awang, Z. (2014). A Handbook on SME: For Academicians and Practitioners. MPWS Rich Resources.

Benyo, A. (2014). English spelling problems among students at the University of Dongola, Sudan. International Research Journal. Educational Research, 5(9), 361-367.

Blackwell, L. S., Trzesniewski, K. H., \& Dweck, C. S. (2007, Jan-Feb). Implicit theories of intelligence predict achievement across an adolescent transition: a longitudinal study and an intervention. Child Development, 78(1), 246-263. https://doi.org/10.1111/j.14678624.2007.00995.x

Bulus, M. (2011, Spr). Goal Orientations, Locus of Control and Academic Achievement in Prospective Teachers: An Individual Differences Perspective. Kuram Ve Uygulamada Egitim Bilimleri, 11(2), 540-546. <Go to ISI>://WOS:000291223700002

Buluş, M. (2016, Aug). Predictive Analysis Among Thinking Styles, Goal Orientations and Academic Achievement of Student Teachers. Yuksekogretim Dergisi, 6(2), 62-71. https://doi.org/10.2399/yod.16.009

Champagne, C. (2015). Children's Implicit Beliefs About Intelligence.

Chen, W.-W. (2015, 2016/05/27). The relations between filial piety, goal orientations and academic achievement in Hong Kong. Educational Psychology, 36(5), 898-915. https://doi.org/10.1080/01443410.2015.1008404

Chen, W.-W., \& Wong, Y.-L. (2014, 2015/08/18). Chinese mindset: theories of intelligence, goal orientation and academic achievement in Hong Kong students. Educational Psychology, 35(6), 714-725. https://doi.org/10.1080/01443410.2014.893559

Costa, A., \& Faria, L. (2018, Jun). Implicit Theories of Intelligence and Academic Achievement: A Meta-Analytic Review [Review]. Frontiers in Psychology, 9, 829, Article 829. https://doi.org/10.3389/fpsyg.2018.00829

De Castella, K., \& Byrne, D. (2015, Sep). My intelligence may be more malleable than yours: the revised implicit theories of intelligence (self-theory) scale is a better predictor of achievement, 
motivation, and student disengagement. European Journal of Psychology of Education, 30(3), 245-267. https://doi.org/10.1007/s10212-015-0244-y

Debicki, B. J., Kellermanns, F. W., Barnett, T., Pearson, A. W., \& Pearson, R. A. (2016, 11//). Beyond the Big Five: The mediating role of goal orientation in the relationship between core selfevaluations and academic performance. The International Journal of Management Education, 14(3), 273-285. https://doi.org/10.1016/j.ijme.2016.05.002

Delavar, A., Ahadi, H., \& Barzegar, M. (2011). Relationship between implicit theory of intelligence, 2* 2 achievement goals framework, self-regulating learning with academic achievement. Proceedings of 2nd International Conference on Education and Management Technology,

Diaconu-Gherasim, L. R., Tepordei, A.-M., Mairean, C., \& Rusu, A. (2018). Intelligence beliefs, goal orientations and children's academic achievement: does the children's gender matter? [Article]. Educational Studies, 45(1), 1-18. https://doi.org/10.1080/03055698.2018.1443796

Dinger, F. C., \& Dickhäuser, O. (2013). Does implicit theory of intelligence cause achievement goals? Evidence from an experimental study. International Journal of Educational Research, 61, 3847. https://doi.org/10.1016/j.ijer.2013.03.008

Dormann, C. F., Elith, J., Bacher, S., Buchmann, C., Carl, G., Carré, G., Marquéz, J. R. G., Gruber, B., Lafourcade, B., \& Leitão, P. J. (2013). Collinearity: a review of methods to deal with it and a simulation study evaluating their performance. Ecography, 36(1), 27-46.

Dweck, C. S. (1986). Motivational processes affecting learning. American Psychologist, 41(10), 1040.

Dweck, C. S. (2000). Self-theories: Their role in motivation, personality, and development. Psychology press.

Dweck, C. S., Chiu, C.-y., \& Hong, Y.-y. (1995). Implicit theories and their role in judgments and reactions: A word from two perspectives. Psychological Inquiry, 6(4), 267-285.

Dweck, C. S., \& Grant, H. (2008). Self-theories, goals, and meaning. Handbook of motivation science, 405-416.

Dweck, C. S., \& Leggett, E. L. (1988). A social-cognitive approach to motivation and personality. Psychological Review, 95(2), 256.

Ehrlinger, J., Mitchum, A. L., \& Dweck, C. S. (2016, Mar). Understanding overconfidence: Theories of intelligence, preferential attention, and distorted self-assessment [Article]. Journal of Experimental Social Psychology, 63, 94-100. https://doi.org/10.1016/j.jesp.2015.11.001

Elliot, A. J., \& Church, M. A. (1997). A hierarchical model of approach and avoidance achievement motivation. 72(1), 218.

Elmahdi, O., Ali, A., \& Hassan, M. (2015). Assessing English Syntactic Structures Experienced by Sudanese Female Students at Secondary Schools,(2013-2014). 6(2), 219-241.

Fraenkel, J. R., Wallen, N. E., \& Hyun, H. H. (2012). How to design and evaluate research in education. New York: McGraw-Hill Humanities/Social Sciences/Languages. 
Gheen, M., Hruda, L., Middleton, M., \& Midgley, C. (2000). Using goal orientation theory to examine the transition from middle to high school. Annual Meeting of the American Educational Research Association, New Orleans,

Gunderson, E. A., Donnellan, M. B., Robins, R. W., \& Trzesniewski, K. H. (2018, Sep). The specificity of parenting effects: Differential relations of parent praise and criticism to children's theories of intelligence and learning goals [Article]. Journal of Experimental Child Psychology, 173, 116-135. https://doi.org/10.1016/j.jecp.2018.03.015

Hago, O. E., \& Ali, M. M. H. A. (2015). Assessing English Syntactic Structures Experienced by Sudanese Female Students at Secondary Schools,(2013-2014). Arab World English Journal (AWEJ), 6(2), 219-241.

Hair, J. F., Black, W. C., Babin, B. J., \& Anderson, R. E. (2014). Multivariate data analysis: Pearson new international edition. Essex: Pearson Education Limited, 1, 2.

Hair, J. F., Hult, G. T. M., Ringle, C., \& Sarstedt, M. (2016). A primer on partial least squares structural equation modeling (PLS-SEM). Sage publications.

Hammad, B. J. (2007). Major Morphological Difficulties of Using English Morphemes Facing ]. Sudanese Secondary School Students Sudan University of Science and Technology

Harackiewicz, J. M., \& Elliot, A. J. (1996). Approach and avoidance achievement goals and intrinsic motivation: A mediational analysis. Journal of Personality and Social Psychology, 70(3), 461.

Hong, Y.-y., Chiu, C.-y., \& Dweck, C. S. (1995). Implicit Theories of Intelligence. In Efficacy, agency, and self-esteem (pp. 197-216). Springer.

Hulleman, C. S., Schrager, S. M., Bodmann, S. M., \& Harackiewicz, J. M. (2010, May). A metaanalytic review of achievement goal measures: different labels for the same constructs or different constructs with similar labels? Psychological Bulletin, 136(3), 422-449. https://doi.org/10.1037/a0018947

Kaplan, A., Middleton, M. J., Urdan, T., \& Midgley, C. (2002). Achievement goals and goal structures. Goals, goal structures, and patterns of adaptive learning, 21-53.

King, R. B., McInerney, D. M., \& Watkins, D. A. (2012, Dec). How you think about your intelligence determines how you feel in school: The role of theories of intelligence on academic emotions [Article]. Learning and Individual Differences, 22(6), 814-819. https://doi.org/10.1016/j.lindif.2012.04.005

Labi, A. G. Y., \& Ahmed. (2005). Investigating Difficulties Facing The Sudanese Secondary School Students in Writing in English as a Foreign Language Sudan University of Science and Technology].

Linnenbrink-Garcia, L., Tyson, D. F., \& Patall, E. A. (2008). When are achievement goal orientations beneficial for academic achievement? A closer look at main effects and moderating factors. Revue internationale de psychologie sociale, 21(1), 19-70.

Martin, A. J., Bostwick, K., Collie, R. J., \& Tarbetsky, A. L. (2017). Implicit Theories of Intelligence. 
Midgley, C., Kaplan, A., \& Middleton, M. (2001). Performance-approach goals: Good for what, for whom, under what circumstances, and at what cost? Journal of Educational Psychology, 93(1), 77.

Mohammed, F. E. (2014). The role of first language in learning English as a foreign language in Sudan. International Journal of English and Education, 3(2), 274-281.

Neroni, J., Meijs, C., Leontjevas, R., Kirschner, P. A., \& de Groot, R. H. M. (2018, Apr). Goal Orientation and Academic Performance in Adult Distance Education. International Review of Research in Open and Distributed Learning, 19(2), 192-208. <Go to ISI>://WOS:000436238200012

Niepel, C., Brunner, M., \& Preckel, F. (2014, Oct). Achievement goals, academic self-concept, and school grades in mathematics: Longitudinal reciprocal relations in above average ability secondary school students. Contemporary Educational Psychology, 39(4), 301-313. https://doi.org/10.1016/j.cedpsych.2014.07.002

Pekrun, R., Elliot, A. J., \& Maier, M. A. (2006). Achievement goals and discrete achievement emotions: A theoretical model and prospective test. Journal of Educational Psychology, 98(3), 583.

Pekrun, R., Elliot, A. J., \& Maier, M. A. (2009). Achievement goals and achievement emotions: Testing a model of their joint relations with academic performance. Journal of Educational Psychology, 101(1), 115.

Piaw, C. Y. (2013). Mastering research statistics. Malaysia: McGraw Hill Education, New York, United States.

Schumacker, R. E., \& Lomax, R. G. (2016). A beginner's guide to structural equation modeling. psychology press.

Siong, T. L., Othman, A. S., Hamzah, S. M., \& Yong, T. H. (2014). Family Environment and Student Academic Achievement English in Remote Schools. Kolej Univ Islam Sultan Azlan Shah. <Go to ISI >://WOS:000360863900013

Spinath, B. (2012). Academic Achievement A2 - Ramachandran, V.S. In Encyclopedia of Human Behavior (Second Edition) (pp. 1-8). Academic Press. https://doi.org/http://dx.doi.org/10.1016/B978-0-12-375000-6.00001-X

Suprayogi, M. N., Ratriana, L., \& Wulandari, A. P. J. (2019). The interplay of academic efficacy and goal orientation toward academic achievement. Journal of Physics: Conference Series, 1175. https://doi.org/10.1088/1742-6596/1175/1/012132

Tarbetsky, A. L., Collie, R. J., \& Martin, A. J. (2016, Oct). The role of implicit theories of intelligence and ability in predicting achievement for Indigenous (Aboriginal) Australian students. $\begin{array}{llll}\text { Contemporary } & \text { Educational }\end{array}$ https://doi.org/10.1016/j.cedpsych.2016.01.002 
Ugur, A. (2016). The explanatory and predictive relationship pattern between university students goal orientation behaviours and their academic achievement. Educational Research and Reviews, 11(17), 1650-1658. https://doi.org/10.5897/err2016.2878

Yengimolki, S., Kalantarkousheh, S., \& Malekitabar, A. (2015). Self-Concept, Social Adjustment and Academic Achievement of Persian Students. International Review of Social Sciences and Humanities, 8(2), 50-60.

Zhou, Y., \& Wang, J. (2019, Jul). Goal orientation, learning strategies, and academic performance in adult distance learning. Social Behavior and Personality: an international journal, 47(7), 120, Article UNSP e8195. https://doi.org/10.2224/sbp.8195

Received: 01-06-2020

Accepted: 12-02-2021 